\title{
IBN KHALDUN'S ILM UL UMRĀN AND HISTORY OF JUDAISM
}

\author{
Munazza Batool \\ Assistant Professor, Department of Comparative Religions \\ Faculty of Usuluddin, IIUI-Islamabad Pakistan, \\ munazza.batool@iiu.edu.pk \\ Shagufta Amir \\ MPhil Scholar, Department of Comparative Religions \\ Faculty of Usuluddin, IIUI-Islamabad Pakistan, \\ iamshaguftaamir@gmail.com
}

\begin{abstract}
Main focus of the paper is the socio-historical studies of Judaism by Ibn Khaldun. Ibn Khaldun's scholarship and his contribution to the various domains of social sciences like history, sociology and politics has been acknowledged globally. While his both works al Ibar and Muqadimmah have remained the focus of many researches dealing with his social scientific theories and historical studies but Ibn Khaldun's approach to the study of other religions has been touched by only few scholars. It is the purpose of this study to examine and analyze Ibn Khaldun's Ilm ul-Umran (science of society) and its correlation with the history of Judaism. In an attempt to highlight and discuss his approach to the study of Judaism the research will firstly discuss his contribution to the study of Judaism in Muqaddimah and then in al Ibar decisively showing his two distinct methods for dealing with the Jewish history and religion. For him, Jews are the best example to explain his Umran science and his socio-historical theories that he has discussed at length in his Muqaddimah. Thus, he takes Jewish history as a prototype for explaining the theoretical framework of his science al Umran. According to him Jewish history is the best example for study of human history and society as they have experienced many rises and falls throughout their history. Likewise, their history is replete with examples of various models of social life; they experienced the dessert and sedentary life, they lost their social and political status many times and regained it by their group solidarity. This study is based on qualitative research design and applies the content analysis to trace and collect the data related to the theoretical and historical study of Judaism scattered in his al Ibar and Muqaddimah and textual analysis to describe, interpret and analyze these themes to frame together a comprehensive approach of Ibn Khadun to study of Judaism.
\end{abstract}

Keywords: Ibn Khaldun, Ilm ul Umran, Jewish History, Social Science

\section{INTRODUCTION}

Wali al Din Abu Zayd Abd al Rahman Ibn Khaldun (732-804AH/1332-1406AD) was a great figure of $14^{\text {th }}$ century CE. Ibn Khaldun's conception of knowledge is not based on one discipline; he contributed to history, politics, economics, sociology and study of other religions. In the field of studying other religions Ibn Khaldun, in his introduction to history Al Muqadimmah, focuses on those religions which are mentioned in Holy Quran for instance Judaism, Christianity, Sabeanism and Mageanism.

Many researchers perceived Ibn Khaldun as an historian of Islamic East and West or the historian of Arabs and Berbers. Thus a discussion of his contribution to the study of other religions appears quite surprising (Walter J. Fischel, 2009, p. 111) but the examination of his contribution to the study of other religions reveals that it is as novel, extraordinary and highly useful like his contribution to history and other domains of social sciences, but neglected in the academic circles (Bland, 1983).

Ibn Khaldun has dealt with the study of other religions in both of his major works namely, Muqaddimah and Kitab al Ibar. Interestingly we find him using two different approaches in both of his works. In Muqaddimah he deals with the study of other religions in light of his conception of knowledge which is based on his science of ilm ul umrān. It is in the light of his theories of ilm ul 
umrān Ibn Khaldun chooses some specific themes of other religions to elaborate his theoretical perspectives. For instance, from many themes of Christianity he discusses only Christian Bible, Nicene Creed the historical development of Christianity and the origin of patriarch or pope. Similarly, from many themes of Jewish studies he focuses on Torah, chosenness of people of Israel, Cohen or Kohen and Jews living in wilderness from the exodus history and Muhammad's name in Torah. While his book on history of the world Kitab Al- Ibar discusses each and every event of religious history of Jews and Christians.

It is his unique approach and study of Judaism that is the key theme of the current paper. Ibn Khaldun offers a good critique and discussion about Jews. For instance, he relates the wilderness of forty years with the rise and fall of nations, likewise he describes the role of religious leadership in Jewish society, relates the concept of chosen people with his 'asābìyāh theory. Indeed, Ibn Khaldun is the first Muslim historian who provides the social, political, psychological and anthropological aspects of Jewish history. Ibn Khaldun deals at length with the political history of Judaism and provides a detailed summery of Jewish political history to his reader (Bland, 1983).

It is important to note here that Ibn Khaldun divides his umrān science in four parts firstly, umrān al-alām (historical aspects), umrān al- bāsharī (anthropological aspects), umrān al-hadārī wa umrān al Badāwì (sociological aspects). Under all these divisions he explains Judaism in his Muqadimmah whereas in kitab al-ibar he adopts only umrān al-alām or historical approach for the analysis of Jewish history.

Ibn Khaldun's Umrān approaches and Judaism: A Socio- Historical Dimension in Muqadimmah In the earlier pages of Muqadimmah Ibn Khaldun describes his idea of umrān, he states that my book of history contains with the political events of Arabs, non-Arabs and the Berbers of Maghrib. It also deals with the supreme rulers who were contemporaries of these nations. He further writes about the origin of races and royal families, concerning the chronological arrangements of earliest nations, the reasons of change within religious groups, dynasties, towns, science and crafts, nomadic and sedentary life. Moreover, he states this book of history deals with actual and future events, and all expected things which can occur in a civilization (umrān)(The Muqaddimah, 2015).

Regarding Jewish studies many Muslim intellectuals have worked on Jews in the field of studying other religions and in the field of history also. Ibn Khaldun has a different approach he discusses their history in a unique way. He relates their history to his umrān science and elaborates many of his theories regarding society through examples from history of Judaism. As it is mentioned previously, Ibn Khaldun's ilm al- umran has four main divisions. Umrān al-alām (historical aspects), umrān al- bashārī (anthropological aspects), umrān al- hadārī wa umrān al badāwī (sociological aspects). Under all these divisions he discusses different themes of Judaism.

Ibn Khaldun argues in first chapter of Muqadimmah that human's social organization is the will of God and we humans are His representatives on earth. He further elaborates, it is necessary for human species to organize socially. The existence of humankind would not be complete without social organization. God's wish to settle this planet of earth with human beings and to make them his representatives on earth would not have taken place. This is the meaning of civilization and the purpose of this science under discussion (Khaldûn \& Lawrence, 2015, p. 46).

This statement of Ibn Khaldun shows that he relates civilizations and societies with the will of God (religion). That is why he has a unique approach for studying Judaism. For him Judaism is not only a religion and history of a nation, but they have a strong connection between religion and social organization.

\section{Umrān Al-Bashārī and Jews ('Asābīyāh amongst Jews)}

Ibn Khaldun's concept of umrān and 'asābiy $\bar{a} h$ are amongst the most widely researched topics by many scholars. Ibn Khaldun was so concerned with his 'asābiy $\bar{a} h$ theory, he explained this concept in many places of Muqadimmah and Tarīkh. He discusses 'asābīyāh in relation to anthropology and sociology, this concept is taken as a main catalyst for development of nations for instance, in the case of Israelites. Ibn Khaldun takes two main themes of Jewish history for discussing his 'asābiy $\bar{a} h$ theory. Firstly, he discusses their concept of chosen people (election of Israel) and secondly, he takes their exodus history. 
First of all, he describes the concept of chosen people in the second chapter of Muqadimmah namely, "only those who share in the group feeling of a group can have a "house" and nobility in the basic sense and in reality, while others have it only in a metaphorical and figurative sense".

Ibn Khaldun states, the nobility is acquired through "asābiy āh or group solidarity. Nations can only possess the nobility by group feel or solidarity. He exemplifies such a nobility through the concept of chosen people by Israelites. He says that Israelites were noble nation for many reasons. Many Prophets were sent in their descent and these Prophets were the founders of many religious laws and religious groups. God bestowed the Israelites with great kingdom (Ibn Khaldun, 2004, pp. 167-168).

Ibn Khaldun describes the concept of chosen people in his Muqadimmah, he writes, in fact Israelites had great houses and glory in the world. The reason for this majesty and nobility was the great number of Prophet $\mathrm{s}$ in their nation, their religious law, the group solidarity and the royal authority which was granted them by the will of God. Then, they deprived from all of the blessings of God, they faced humiliation before God and before the world also. They were doomed to live as expatriate on this earth. For thousands of years, they lived in slavery and unbelief. Still, they are living in the delusion of nobility. Jewish people can be found saying that he is a descendent of Aaronite or Joshua, he is one of Celeb's descent he is from the family of Judah, in spite of this fact that they lost their group solidarity (Ibn Khaldun, 2004, p. 168).

According to Ibn Khaldun Jews had such an honor from two sources, their ancestry and their group feel or solidarity. The first source refers to the great numbers of Prophets. Having a great number of Prophets and messengers indicates a distinct position of Jews among many other nations of the world. In the same way they have divine message which also signifies their dignity as seen in their concept of Jews as elected people.

Ibn Khaldun states, God promised them the group solidarity 'asābìyāh. In his view this group solidarity 'asābiyanh came from the royal authority which God promised to them. However, they lost their special status and punished by God because of their misdeeds. Until Ibn Khaldun's time Jews were in the delusion of their special status of chosen people, tells Ibn Khaldun.

In Christianity the concept of chosen people is abrogated by the idea of replacement of theology. Christians have belief that due to their submission to the teachings of Jesus they gained this status of chosen people (Avi Beker, 2008, pp. 1-13).

Similarly, from Islamic perspective, there are many verses in Holy Quran which address this special status of Jews (al-Baqārah 2:47; 122, al-Mā'̄ìdah 5:20, al-Araāf 7:137; 140, al- Sājadāh32:23 and 24). However, this special status is nullified in other verses due to wrongdoings of Jews (Wan Mohd Farzul Azadi Wan Razali, 2017, p. 259).

The second theme which Ibn Khaldun discusses in context of 'asābiy $\bar{a} h$ is the exodus history of Jews. Interestingly exodus is not mentioned only in the Hebrew Tanakh but it is also mentioned in Christian Bible and Holy Quran.

It should be remembered that exodus has importance among all of the three Abrahamic religions. In Judaism Pesach or Passover is celebrated for liberation of Jews and blessings of God as Ibn Khaldun states in the book of lessons (Ibn Khaldun, 2000, p. 94). In Christianity the savior character of Prophet Musa A.S has a significance when he saved his people from the dangers of the world and faith. For Muslims importance of exodus is illustrated by Prophet Muhammad himself. Prophet Muhammad remarks that Muslims are closer to Prophet Musa A.S than anyone else. There is a Hadith of Prophet which signifies its importance.

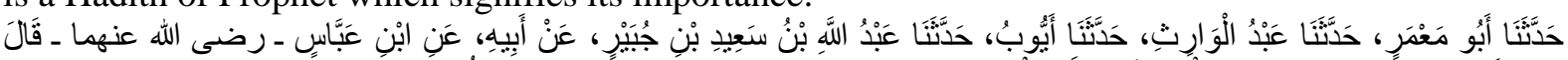

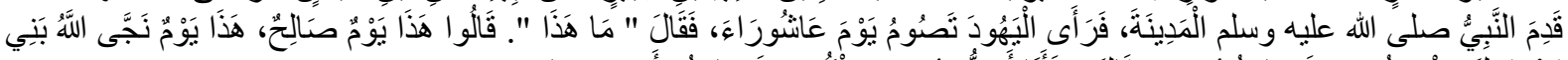

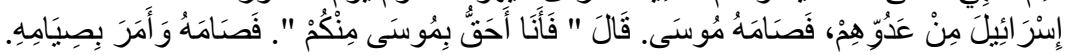

Ibn Abbas R.A. said: The Prophet S.A.W. came to Madinah and saw the Jews fasting on the Day of Ashura'. He asked, "What is this?" They said, "This is a righteous day, it is the day when Allah saved the Children of Israel from their enemies, so Musa A.S. fasted on this day." He said, "We have more right to Musa than you," so he fasted on that day and commanded (the Muslims) to fast on that day

(Bukhari, 1998, Hadith No.2004).

Ibn Khaldun describes the complete history of Exodus in his kitab al-ibar in the chapter on al-Khābār An Bānī Isrāel Wa Mā Kānā Lāhūm Mìn al-Nûbūwwāh Wa al-Mūlk (Abd Al- Rahman Ibn Khaldun, 2000, pp. 92-166) While in Muqadimmah he only quotes a particular part, which relates to 
his need. In chapter two of Muqadimmah he explains the lessons from exodus history. In his view the Israelites are a good example for explaining royal authority and sovereignty.

When Prophet Musa A.S urged them to become the rulers of Syria and told them that they are destined to this by God. But the Israelites were weak because of slavery of Egyptians. They denied fighting for the land of Syria and said they cannot face those giants in that country. They became rebellious and disobeyed to the will of God. They said to Musa A.S: Go you yourself and your lord, and fight.(Al-Quran,5.29) Hence, they were left in the desert for wilderness (The Muqaddimah, 2015, p. 110).

He further elaborates that this attitude of Israelites was the result of docility and subservient to Egyptians which they acquired through a long time. Eventually they completely lost their 'asābìyāh or group solidarity. They did not believe what their Prophet told them, and they denied claiming the holy land. For that Allah Almighty punished them to remain in the desert for forty years. They stayed in desert between Egypt and Syria for forty years, they had not any contact with civilization nor they settled in any city as it is told in Holy Book of Allah (Al-Quran, 5:26). His interpretation of forty years of wilderness was meant to develop a new generation of Jews who could execute the commands of Prophet and face the challenges and difficulties with courage. He asserts, forty years is the period in which a generation can disappear and new one can rise (The Muqaddimah, 2015, p. 111). The new 'asābiy $\bar{a} h$ could encourage the people of Israel for the pursuit of a kingdom in Holy Land. The important point to note here is, Ibn Khaldun asserts that the best 'asābiyya $h$ can be found among nomadic people of desert. Thus, desert becomes best place to build an 'asābiy $\bar{a} h$ or group solidarity. Perhaps this was the purpose of their wilderness in desert.

Such findings of Ibn Khaldun are very interesting and different from other historians. According to Solomon Pines (1908-1990), a well-known Israeli scholar of Islamic and Jewish Philosophy, Ibn Khaldun's findings on forty years of wilderness are correspond to Moses Maimonides (1135-1204) work namely Guide to the Perplexed (Pines, 1970). Although the idea of punishment is not denied by Ibn Khaldun but it is different from the one mentioned in Torah, The interpretation of forty years' wilderness by Ibn Khaldun and Moses Maimonides prove to be more in keeping with Qur'anic verse which has emphasis on Israelites wandering in the wilderness for forty years, whereas in the book of Exodus the emphasis is on the destruction of the previous generation without seeing the land. Therefore, Ibn Khaldun's interpretation is more parallel to Qur'anic account than other Muslim classic scholars whose interpretation goes parallel to Biblical account (Salime Leyla GÜRKAN, n.d., pp. 109-110).

These two themes of Jewish history explain 'asābiy $\bar{a} h$ theory in detail. The idea of Chosen people describes how Israelites managed to re-establish their 'asābiy $\bar{a} h$ or group feel. The exodus history explains how they lost their 'asābìy $\bar{a} h$ during the slavery of Egyptians and then in forty years of wilderness they regained their 'asābiy $\bar{a} h$ to achieve a social status.

Interestingly, at present time, many Israeli scholars are urging their people to establish a new 'asābīy $\bar{a} h$ according to Ibn Khaldun's theoretical patterns:

Israel cannot afford to take Ibn Khaldun lightly. It needs 'asābiȳāh to deal with its many foes, some of whom are Israeli Arab citizens when they act collectively not as individuals (Pro. Hillel Frisch, 2018).

Gerald A. Honigman states in Israel National News that Ibn Khaldun would have fully apprehended the rebirth of Israel by 'asābiy $\bar{a} h$ or group solidarity. The religious Zionism has correspondence to Ibn Khaldun's idea of 'asābìyāh (What Would Ibn Khaldun Say? - Israel National News, n.d.).

\section{Umrān al- Hadārī wa al Badāwī (Authority of Cohen In Jewish Society)}

Ibn Khaldun discusses the role of religious leadership in different religions in the third chapter of Muqadimmah. He discusses the religious leadership of Muslim, Jewish and Christian communities. His remarks on the origin of Cohen and Patriarch are very important. The discussion on Cohen and Patriarch is in the subchapter namely "remarks on the words Pope and Patriarch in Christian religion and on the word, Kohen used by the Jews" (Abd Al- Rahman Ibn Khaldun, 2001, pp. 287-292).

He describes it in a detailed note of his Muqadimmah, in his view a religious group must have someone after the death of Prophets to take care of their religious obligations. He should be such a person who could guide his people to act according to their religious law. Furthermore, he explains, the person is not only a religious leader, but he acts as a political and social leader. He encourages his 
people in good deeds and prevents them by force in bad deeds. These qualities enable him to call a ruler (The Muqaddimah, 2015, p. 183).

Ibn Khaldun explains the vital role of religious leadership in human history. Regarding Judaism, firstly he describes the fundamental concept of Prophethood. In Holy Quran Jewish people are prescribed as ahl al-kitab the people of book. According to Islamic Perspective Judaism originated from the teachings of Prophets. That is why the religious leadership belongs to the lineage of their Prophets.

Furthermore, Ibn Khaldun argues that after Prophet Musa A.S and Prophet Joshua PBUH, the only concern of Israelites was to establish their religion. The person who was their religious leader was called Kohen or Cohen. He was a representative (like Caliph in Islam) of Prophet Musa A.S. His fundamental duty was to regulate prayers and sacrifices of Israelites. A condition was made for Kohen to be a person from Banu Haroon A.S (Aaronites), as it was destined for Prophet Haroon A.S and his children by divine revelation. For political matters Israelites selected seventy elders with a general legal authority. The Kohen was higher than elders in legal authority (The Muqaddimah, 2015, pp. 184-185).

It is possible to say that Ibn Khaldun's analysis on Cohen in his Muqadimmah refers to the Jewish sources which he used in his work for instance Holy Torah, Israeliyat of converted Jews of Himyarites (Ka'ab al- Ahbar and Wahab Ibn Munabbih), Hebrew chronicle of Yusuf ibn Kuryun. He correctly traces the origin of Cohen from the lineage of Prophet Haroon A.S.

In other words, Ibn Khaldun says that after removal of a Prophet Cohen is the one who creates a group feeling or 'asābiy $\bar{a} h$ among his folks. Through performing religious rituals and guiding people in the matters of religion he provides a platform to unite people and by uniting folks he becomes the cause of group solidarity or group feel.

However, Jews are the nation who suffered wars and foreign invasions several times throughout their history. According to Ibn Khaldun due to these wars people of Israel lost their 'asābiy $\bar{a} h$ and eventually their state. Yet the role of Cohen remained significant in the Jewish history because of his social and religious duties.

\section{Umrān al Alām (Ibn Khaldun's Theory of Dynastic Cycle and Holy Torah)}

The Holy Torah is among the main sources of Ibn Khaldun's work on Judaism. Several times he refers Torah in his Muqadimmah and Kitab al- Ibar. He mentions references from Torah for the genealogy of Prophets, history of Prophets, in remarking the role of Cohen in Jewish society, to explain his theory of prestige lasts at best four generations in one lineage, to explain dynasties have natural life span like individuals, in discussion of Jewish Tabernacle (al-qubbah) and Ark (al-täbüt), in discussion of destruction of first temple by Nebuchadnezzar II (605-562 BC) and the Torah references for the old religious law of the Jews.

In the second chapter of Muqadimmah, in subchapter fourteen "prestige lasts at best four generations in one lineage" (Ibn Khaldun, 2004, pp. 268-270), he explains this theory by a reference from Torah, he states as follow:

In Holy Torah, there is the following passage: "God, your Lord, is powerful" (Exodus 20:5) and jealous, visiting the sins of the fathers upon the children unto the third and the fourth (generations)."

This shows that four generations in one lineage are the limit in extent of ancestral prestige (The Muqaddimah, 2015, p. 106).

He further explains, when a group of people achieves the royal authority and nobility by the group solidarity or 'asābiy $\bar{a} h$ their prestige lasts at the best to four generations. After four generations their downfall begins because their 'asābiy $\bar{a} h$ weakens. He explains that when a tribe or a group of people achieves their purpose and experience the luxurious life in civilized cities gradually their 'as ābiy $\bar{a} h$ vanished. From this reference of Torah, he explains that 'asābiy $\bar{a} h$ remains till four generations in one lineage.

He also describes a saying of Prophet Muhammad, the noble son of the noble father of the noble grandfather of the noble great grandfather: Prophet Yusuf A.S the son of Prophet Yaqoob A.S, the son of Prophet Ishaq A.S, the son of Prophet Ibrahim A.S. Then he states that this indicates, Yusuf A.S had reached the limit of glory (Khaldûn \& Lawrence, 2015, p. 107).

In the $3^{\text {rd }}$ chapter of Muqadimmah (Ibn Khaldun, 2004, pp. 335-337) he argues that the life of a dynasty does not extend beyond three generations and an individual has an average life of forty 
years. So, a dynasty has a life span of 120 years. After 120 years the downfall begins normally. The first generation retains the qualities of desert toughness and is strong in 'asābiyāh or group solidarity therefore they rule with strength and power. The second-generation changes from the desert attitude to sedentary thus their 'asābiya $\bar{h}$ begins to weaken. Only one person claims to be in power and others are too lazy to strive for the glory and power. The third generation completely forgets the period of desert toughness and their group solidarity disappears completely. They forget to defend themselves and try to find some other clients and followers to protect them. These clients are almost from desert people and then a time comes when these desert people claim glory and power for themselves hence the fourth generation witnesses the fall.

Ibn Khaldun's presentation of dynastic cycle is parallel to organismic theories of modern sociology. As Ibn Khaldun, Herbert Spencer (1820-1903) also compares the state with an individual. For Spencer, states are subjected to the laws of growth and decay like individuals. A state has its childhood, youth, old age and death like humans (Cooley, 1920).

Although, the dynastic cycle of Ibn Khaldun is criticized by many scholars yet others argued, we should not compare him with present scholars of international relations and political science. The atmosphere in which Ibn Khaldun lived, was very different from present scenario of the world. The perception of our world is not the same with Ibn Khaldun's era (Yücekaya, n.d., p. 145).

\section{History of Judaism in kitab al- ibar}

$K \bar{l} t \bar{a} b a l-\bar{\imath} b \bar{a} r$ or book of lessons is the main work of Ibn Khaldun which comprises on seven volumes. Kitab al-ibar records the main and major events of the world's nations. Like many other historians he starts the first volume of his book from Prophet Adam A.S and Nuh A.S. His discussion begins, in detail from the life of Prophet Ibrahim A.S. From here he starts the history of Jews and Arabs.

Although, his emphasis is on political and social history of Judaism which he relates to the theory of rise and falls of dynasties, he also offers, what politics talks about the human nature.(Roy Jackson, 2006, p. 132) In the first volume of kitāa al- $\bar{\imath} b \bar{a} r$ there is a detailed description of Jewish history. This description provides the reader a whole picture of their history.

\section{Prophet Ibrahim A.S and his descendants}

Ibn Khaldun begins the discussion with the non-Arab ajāmi origin of Prophet Ibrahim A.S in his kitab al- ibar/ book of lessons. He says, Prophet Ibrahim A.S is the $3^{\text {rd }}$ ancestor of human beings after Prophet Adam A.S and Prophet Nuh A.S. Ibn Khaldun argues that there is a controversy between historians on birth place of Prophet Ibrahim A.S. According to Al-Tabari and Ibn Ishaq Prophet Ibrahim A.S was born in the land of kosa (sawad) and for some others he was born in Harran or Babylonia. He states that Tarah and Aazar was the names of same person who was the father of Prophet Ibrahim A.S (Ibn Khaldun, 2000, p. 36). Furthermore, he highlights a statement of Torah about the birth of Prophet Ibrahim A.S. He states that there is a strange thing in Torah which is, at the time of Prophet Nuh's death Prophet Ibrahim A.S was fifty-three years old. He mentions this statement in a speculative manner.

Ibn Khaldun then refers to the incidents and details of the birth and early life of Prophet Ibrahim in light of Torah and Quran.

The most interesting departure of Ibn Khaldun about the biography of Prophet Ibrahim A.S is his view about zabeeh ullah. Here he refers to the disagreement between scholars' whether Prophet Ishaq A.S was chosen by Allah for sacrifice or it was Prophet Ismael A.S. He says that Ibn Abbas, Ibn Umar, al-shu'abi, Mujahid, Hassan, Muhammad bin Ka'ab al-qarzi are the scholars who believe, Prophet Ismael A.S is the zabeeh ullah. They proved this claim by giving an example of Prophet Muhammad敏's Hadith;

"I am the son of two zabeeh 'in the sacrificed ones".

It means Prophet Muhammad pointed to the sacrifice of Prophet Ismael A.S and his father Abdullah. Yet according to Ibn Khaldun, sometimes people used word of father for their uncles. It is not clear that Prophet said this about Prophet Ismael A.S or Prophet Ishaq A.S. He further explains, many companions of Prophet Muhammad such as Abbas, Umar Ali, Qatadah R.A had also the opinion that Prophet Ishaq A.S was sacrificed. Al- Tabari adopted their opinion that Prophet Ishaq A.S was the sacrificed one (Abd Al- Rahman Ibn Khaldun, 2000, pp. 41-43). 
The translator of Tarikh Ibn Khaldun, Hakeem Hussain Alah-Abadi mentions, this view of Ibn Khaldun is not acceptable because sacrifice of Prophet Ishmael A.S has proven by the Hadith of Prophet Muhammad (Abd Al- Rahman Ibn Khaldun, 2003, p. 61). Unlike Quran, in Tanakh it is clear that God commanded Prophet Abraham PBUH to sacrifice Prophet Isaac PBUH in the land of Moriah (Hebrew English Tanakh: The Jewish Bible, 2009, p. 37). Although Ibn Khaldun did not

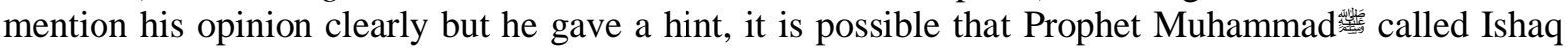
A.S his father.

\section{Prophet Yaqoob A.S and Start of Israelite's History:}

After the biography of Prophet Ibrahim A.S. ibn Khaldun proceeds to the description of the history of Prophet Ishaq A. S, and his son Yaqoob A.S and provides the details of his family. Here we also find his detailed interest in the description of the story of Prophet Yusuf A.S.

For instance; his dream, jealousy of his brothers towards him that resulted in leaving him in a well, story of caravan taking him to Egypt, the incident between Prophet Yusuf A.S and Zulaikha, his time in prison and his interpretations of dreams during prison, his vizierate in the court of pharaoh (Abd Al- Rahman Ibn Khaldun, 2003, pp. 72-79).

Ibn Khaldun provides interesting details about the life of Prophet Yusuf A.S that are based on the accounts of Quran and Torah like; after twenty years Prophet Yusuf A.S met his father, Prophet Yaqoob A.S lived in Egypt with his family for seventeen years almost. When Prophet Yaqoob A.S died, Prophet Yusuf A.S came in Canaan for his funeral and burial. Prophet Yusuf A.S died in the age of one hundred and twenty years. He bequeathed to Israelites, when you return to your homeland, take my corpse with you and burry me in the land of Canaan. After him children of Israel lived between Egyptians, became prosper and flourished in numbers. Then a time came when pharaohs began to fear of their growing numbers and started taking service from them. Eventually they became their slaves. We find Ibn Khaldun also differs with many historians about Prophet Yusuf A.S eventually gaining the kingdom of Egypt. Some Quranic exegesis experts also believe this and they present a verse from Surah Yusuf as a proof.

My Lord, You have given me [something] of sovereignty and taught me of the interpretation of dreams. Creator of the heavens and earth, You are my protector in this world and in the Hereafter.

Cause me to die a Muslim and join me with the righteous."(Al-Quran, 12.101).

Ibn Khaldun argues that in Arabic language the word mulk sovereignty has a use for house, horses, servants and power. This was a tradition in Arabs, they used to say mulük for elite classes. He narrates the example of officials of Abbasid Caliphate who were called by Arabs as mulük. He accepts the saying of Torah about Prophet Yusuf A.S that he was a vizier of Pharaoh (Ibn Khaldun, 2000).

\section{Prophet Musa A.S and Exodus of Israelites}

In the story of Prophet Musa A.S there is a disagreement of historians, some states that in Midian, he met Prophet Shoaib A.S while other believe that he was a scholar and a religious leader named Ravel. Ibn Khaldun also had this opinion that he was Prophet Shoaib A.S. He lived in Midian with his fatherin-law and returned to Egypt when he was in the age of eighty. By the will of Allah SWT Prophet Musa A.S and Prophet Haroon A.S invited Pharaoh to the way of Allah, but they failed to convince him. Allah SWT smacked the Egyptians with terrible plagues including a river of blood, many frogs, death of their sons. After many years of torture, Israelites migrated by the will of Allah. Jews celebrate this day every year and called it Passover or Pesach (Eid al- Faseeh). The primary significance of this festival relates to redemption of Israelites from Egyptian slavery (Reuven Firestone, n.d., p. 177).

When Israelites left Egypt, they were six hundred thousand (Although Ibn Khaldun does not agree by the figure) in numbers. Soon Pharaoh chased them and reached on Nile river. Prophet Musa A.S by his miraculous stick made the way for passing river and people of Israel passed easily. When Pharaoh along with his army followed them, Allah SWT drowned them in the river.

People of Israel abided near mountain of Toor and here Allah SWT gave Ten Commandments to Prophet Musa A.S. After three months of their arrival in the dessert of Sinai, Allah SWT ordered them to claim the land of Palestine which He promised to Prophet Ishaq A.S and Prophet Yaqoob A.S. when they reached near the state of Amalekites and Canaanites, they denied to fight in the way of Allah. Allah SWT punished them and they remained in wilderness for forty years. They fought 
with some Canaanites kings and defeated them. Then they began to commit adultery with women of Midian and Moab and again punished by Allah SWT by the black death. Many people died during this plague until a time came when a new generation of Israelites was there who was not in the influence of slavery. Prophet Musa A.S died in the age of one hundred and twenty years. After him they fought with many nations and conquered some small states (Ibn Khaldun, 2000, pp. 93-96).

\section{Kingdom of Israelites}

Ibn Khaldun discusses the political and moral situation of Israelites. They abandoned their shariah and avoided their religious duties, invaded by many nations of neighboring regions. Three hundred years passed, and they were still suffering, until Prophet Samuel PBUH prayed for a king who could lead them and Allah SWT rewarded them with a strong leader named Saul (Taloot). Allah SWT asked prophet Samuel PBUH to assist him. Allah Almighty granted him strength and rewarded him with triumphs. But Prophet Samuel left Saul when he granted freedom to an Amalekite king, without consulting him. Prophet Samuel PBUH chose Prophet Dawood A.S by the will of Allah. He defeated the Palestinian king Goliath (Jaloot) and became the leader of Israelites. He reigned over them for forty years.

After death of Prophet Dawood, A.S, his son Prophet Suleiman A.S succeeded him. He was twenty-two years old when he sat on his father's throne. He built the Bayet ul Haykel temple mount and al-Aqsa mosque; his reign was at the peak of progress and prosperity. Many neighboring states submitted before him he had one thousand wives and many sons. During his reign there was abundance of Gold and silver. Ibn Khaldun states about the trade during reign of Prophet Suleiman A.S. He says, many ships used to sail across the Indian ocean for import and export of gold, silver, ivory and much more.

When he states the submission of queen of Sheba before Prophet Suleiman A.S, he mentions that scholars of Jews do not accept Prophet Suleiman's marriage with queen of Sheba. They also have belief that he never went to the land of Yamen. She submitted to Prophet Solomon only by letters. He further adds, all this is written in their book of Kings (Abd Al- Rahman Ibn Khaldun, 2000, pp. 113114)'.

Prophet Suleiman A.S died after forty years' rule, in Holy Book of Allah there is a whole Surah "Al-Naml" which describes the story of Prophet Suleiman A.S. After the death of Prophet Suleiman, A.S, people of Israel divided into two groups and began to fight with each other for power(Abd Al- Rahman Ibn Khaldun, 2003, pp. 152-160).

\section{Division and Fall of Israelites}

Prophet Suleiman's son Rojbu'um failed to keep the kingdom united. Ten northern tribes rebelled and established their own independent kingdom named Israel, while other two tribes (descendants of Benjamin and Judah) were in southern kingdom named Judea. The southern kingdom was ruled by Davidic dynasty. Some two hundred years people of Israel remained in division (Ibn Khaldun, 2000, pp. 16-20).

Ibn Khaldun explains that northern kingdom of Israel became weak economically, culturally, politically and especially religiously. They abandoned their religious practices and killed many Prophets. People of Judean kingdom were less in numbers and also became weak. The kings of Israelites were sometimes at war and sometimes close allies. Ibn Khaldun mentions, Bayet al-Haykel saw its first destruction by the king of northern kingdom. He looted the temple and destroyed the wall of Prophet Solomon's temple. After fourteen years, Sanjareef the king of Musal attacked the kingdom of Judah, conquered her several cities along with holy city of Jerusalem. He looted the treasures of temple and implemented high taxes on the inhabitants of Judean kingdom. Prophet Isiah PBUH cursed on the army of Sanjareef and half of his army died of plague in one night. After that he returned to his city. During the time of king Yoash of Judah, Pharaoh Aerij (Sheshnoq)was the ruler of Egypt. He encouraged the breakup of Israelites monarchy and marched up towards the Jerusalem for Prophet Suleiman's Gold and Silver. He looted Israelite's kingdoms and fixed a heavy tax on them (Abd Al- Rahman Ibn Khaldun, 2000, pp. 116-122).

Pharaoh Sheshonq's invasion is the first biblical event confirmed by archeology (Montefiore, 2011, p. 38). After seven years, Nebuchadnezzar from Babylonia invaded Israelites, at that time AlYaqim was ruler of Israelites and he was loyal to Pharaoh Sheshonq, but later on he submitted to 
Nebuchadnezzar. For some years they gave taxes to Nebuchadnezzar but Al-Yaqim created problems in collecting taxes. Nebuchadnezzar again invaded the kingdoms of Israelites plundered the city of Jerusalem looted treasures of Prophet Suleiman's temple and took ten thousand Israelites to Babylonia as slaves. Prophet Daniel, Chananya, Mishael and Azariyah (peace be upon them) were among those slaves (Ibn Khaldun, 2000, p. 123).

According to Tabari the exiled Jews settled around the state of Iraq until the Persian king Korosh (Cyrus) sent them back to their Holy Land of Jerusalem. In Israelite's accounts, Nebuchadnezzar was the descendant of Nahur bin Azir (Tarah) from family of Prophet Ibrahim A.S (Abd Al- Rahman Ibn Khaldun, 2003, p. 165).

\section{Restoration of The Holy Land and Arrival of Macedonians:}

Israelites returned to the Jerusalem under the leadership of Prophet Daniel PBUH, king Cyrus gave them gold and silver to restore their life in Holy Land and to rebuild Al- Aqsa mosque. After Prophet Daniel PBUH, they divided again and established their kingdoms on the previous pattern. As in previous discussion, it is stated that ten tribes of Israel abandoned their religious practices, now they started idol worship and they built their own temple. Prophet Ilyas PBUH cursed them and Allah SWT punished them with famine. After three years of suffering, they said Prophet Ilyas PBUH to pray for them. Most of the time both kingdoms were at war. Many Prophets killed by Jews during this time of great turmoil. During these wars, they lost their rule in Samra which was conquered by king of Musal. Many times, Israelites fought with Samra's authorities because they were a major hurdle in completion of temple of Solomon (Ibn Khaldun, 2000, pp. 131-136).

Furthermore, Ibn Khaldun highlights that Samaritans were converted Jews, they were not from the bloodline of Prophet Ishaq A.S. They belonged to a place named Samra and they were decedent of Assyrians.

People of Israel remained in peace during the time of Persian King Cyrus, until in the reign of Darius (Dara) Persian kingdom defeated by Greeks under the leadership of Alexander. Holy Land was under the Persians therefore Greeks marched towards the Holy City of Jerusalem. Cohens of Israel were afraid but beyond hope Alexander did not plunder the city.

He entered in temple of Prophet Suleiman A.S, gave a huge amount of treasure for temple and respected Cohens of temple and left Jerusalem. Alexander asked the high priest to put his portrait in the temple of Solomon, but high priest denied that it is not permissible in the religion of Israelites. And told him, this year every Jewish newborn will be named Alexander in his honor.

After his death, his state distributed among his commanders. The Holy Land was under the Seleucus who first sacked Jerusalem for the treasures of temple but later he regretted and fixed an annual amount of gold for the temple. During the time of Greeks Tanakh translated into Greek language for the first time (Abd Al- Rahman Ibn Khaldun, 2000, pp. 137-138).

The Septuagint Bible changed the history of Jerusalem and later made possible the spread of Christianity. Thanks to Alexander, Greek was the international language; now, for the first time, the Bible could be read by Virtually everyone (Montefiore, 2011, p. 67).

A Greek speaking Jewish community founded and later on Jews were forced by Greek kings to adopt their culture and religion. When Jews denied following their religion Greeks invaded them, persecuted and slaughtered them. The Remaining Jews left Jerusalem and fled to the mountains. They revolted against Hellenistic tyranny and reestablished their priesthood in Temple of Prophet Suleiman A.S. This revolt is called Mateteya (Maccabean) revolt in the history, Jews reoccupied the kingdom of Judea and founded the Maccabean or Hasmonaean Hasamnai dynasty (Abd Al- Rahman Ibn Khaldun, 2003, p. 177).

Furthermore, Ibn Khaldun mentions Jewish sects during the time of Hasmonean dynasty. He states according to Ibn Kuryun there were three sects of Jews at that time. First one was the sect of Farosheem (Pharisees), they were interpreter of Torah. The second one was Saduqiya (Sadducees) they were like Zahiris in Islam. And the third sect was of ubaad al-munqtain they were called as Haiseed (the Essenes). They withdrew from the worldly affairs and used to engage themselves in worship (Abd Al- Rahman Ibn Khaldun, 2000, p. 142).

The discoveries of north-west shore of dead sea (dead sea scrolls) explored that Essenes were the dwellers of Qumran valley. They abandoned themselves from other Jewish communities because of their corrupt religious practices. 


\section{The Romans in Jerusalem and Birth of Messiah}

Ibn Khaldun elaborates, when Bani Hasmnai (Hasmoneans) founded an independent state of Jews and they were fighting with Greeks on different borders, this was the initial stage of Romans expansion towards the Hellenistic empires. He states Romans were occupying their states one by one, when they entered in Antioch, they heard many stories from Greeks about Solomon's temple and its treasures. Roman general (Phamquos) Pompey sent his commanders one by one to the Kingdom of Judea and eventually they entered into city when Jews were performing their rituals on Sabbath.

Romans were at war on the Persian borders, they accepted the annual taxes from Jews and left their generals among them to look after the city of Jerusalem. But soon after a proxy war started between Roman General Pompey and Julius Seizure. And the kings of Hasmonaean Dynasty Hyrcanus (Harqanoos) and Aristobulus became pawns between Julius Seizure and Pompey. After the death of Pompey Roman Seizure ended the Hasmoneans rule and installed Herodian's rule in the Kingdom of Judea. Herodians became a client state of Romans (Abd Al- Rahman Ibn Khaldun, 2000, pp. 140-144).

During the reign of Hasmonean ruler Hyrcanus, Judea conquered Edom (most of territory is now divided between Israel and Jordan) and forced Edomites to convert to Judaism. The Edomites gradually integrated into Judean nation, some of them reached in high-ranking positions in court of Hasmonaeans. Later on, these Edomites became the rulers of Judean state with the help of Romans and founded the Herodian dynasty.

When the rule of Herod became strong, he intended to rebuild the temple of Solomon, he completed it in eight years and permitted common people to visit and perform rituals. This was an age of peace and prosperity for Jews under the Herod king (Abd Al- Rahman Ibn Khaldun, 2003, p. 195).

Ibn Khaldun elaborates, that during the time of Herod the father of Mariam A.S was a high priest. And Mariam's mother was the sister of Prophet Zachariah's wife and her mother's name was Hanna (Anne), while her father was Imran. Ibn Khaldun says, in Jewish sources his name is (Yavaqeem) Joachim. There could be two possibilities, maybe Imran and Joachim are the same in Arabic and Hebrew or maybe the same person had two names. Anne vowed that if she would become a son's mother, her son will be the priest in holy house of God. But she gave birth to a girl and decided to give her for the service of God. Mariam A.S grew up in the house of Zachariah and became a humble saint of God.

Then Allah SWT granted Zachariah and his wife Eisha a son during their old age, named Yahya, John the Baptist (Ibn Khaldun states the name of prophet Yahya in his book of lessons as John the Baptist Yuhana al Muamdan).

Prophet Yahya A.S became the leader of Cohens, he used to live in forests and spent a very humble life. During those days Antefs bin Herodus (Antipas Herod) was the ruler of Judea. He married to his sister-in-law forcefully which was unlawful in Jewish religious law. Prophet Yahya A.S with other Cohens tried to stop him but he killed all Cohens along with Prophet Yahya A.S (Ibn Khaldun, 2000, pp. 167-170).

Ibn Khaldun argues that there are different opinions of Jewish and Muslim scholars about Prophet Zachariah's death. Some of them says that before the death of Yahya A.S he died but some others state when Jews killed Yahya A.S he hid in a tree, and they cut him along with tree. He prefers the opinion of Yaqoob bin Yusuf bin Najar (Yaqoob bin Yusuf bin Najar was a Christian historian. Ibn Khaldun takes many references from his writings) Yusuf wrote that Herod's soldiers killed Zachariah when they were searching Isa A.S and Prophet Zachariah A.S did not tell them, where was he (Abd Al- Rahman Ibn Khaldun, 2003, p. 224).

Wahab Ibn Munabbih states that when Eisha (wife of Zachariah) was pregnant, at the same time Mariam A.S was also pregnant. Her fiancé Yusuf was afraid of Jews and he took her to the Egypt. When they were on the way Prophet Issa A.S was born. When he was twelve years old Mariam A.S bring him back to the Jerusalem. He met with Yahya A.S when he was thirty years old, Yahya A.S baptized him. This was the time when Jews killed Yahya A.S. After some time, they planned to kill Jesus, arrested him and took him to the Roman commander Pontius Pilate (Filatesh). After trial he ordered his death on cross. There is a disagreement between Muslims and Christian about his death (Ibn Khaldun, 2000). 


\section{CONCLUSION}

Ibn Khaldun's book of history and Al-Muqadimmah are not separate from each other. Although many researchers do not consider his book of history, but it has an important link to his sociological discussions in Muqadimmah. In other words, for Ibn Khaldun history and sociology are related to each other.

Ibn Khaldun discusses this history of Jews in the first volume of kitab al-ibar. In his first volume he starts the history of world from Prophet Adam A.S and Prophet Nuh A.S and he starts history of Jews from Prophet Ibrahim A.S. Ibn Khaldun takes references not only from the Muslim sources but also from Jewish and non-Jewish sources. He uses the sources of Tabari, Masudi and Ibn Ishaq. He prefers the Jewish historical sources of Yusuf bin Kuryun. He also quotes Christian historians named Horosius and Ibn Amid many times.

Ibn Khaldun is a historian who focuses on formulating of dynasties, achieving social and political authority. Throughout his work on Judaism the focus is on political and social history of Judaism and he specifically highlights the role of their religious leaders in their political and social matters.

Ibn Khaldun takes references from Torah to explain his main theories of umrān science. The history of Judaism plays a significant role in Khaldunian studies. Indeed, Jews were the best example for Ibn Khaldun to explain his social theories because the nation of Jews had many ups and downs throughout the history. They were also a best example for Ibn Khaldun because they experienced desert and sedentary life many times. His socio-historical approach gives a unique perception of Jewish history. Ibn Khaldun's scientific attempt to study of history paved the way for scientific study of Judaism.

\section{BIBLIOGRAPHY}

Abd Al- Rahman Ibn Khaldun. (2000). Tarikh Ibn Khaldun (Khalil Shihadah, Ed.). Dar al- Fikr.

Abd Al- Rahman Ibn Khaldun. (2001). Muqadimmah Ibn Khaldun (Suhayl Zikaar, Ed.; Vol. 1). Dar al- Fikr.

Abd Al- Rahman Ibn Khaldun. (2003). Tarikh Ibn Khaldun (Hakeem Ahmed Hussein Ala-Abadi, Trans.; Vol. 1). Nafees Academy Press.

Al-Quran. (n.d.).

Avi Beker. (2008). The Chosen: The History of an Idea, the Anatomy of an Obsession. Palgrave Macmillan.

Bland, K. (1983). An Islamic Theory of Jewish History: The Case of Ibn Khaldun. Journal of Asian and African Studies, 18(3), 189.

Bukhari, M. bin I. (1998). Sahih Bukhari. International Ideas Home for Publishing and Distribution.

Cooley, C. H. (1920). Reflections Upon the Sociology of Herbert Spencer. American Journal of Sociology, 26(2), 129-145.

Hebrew English Tanakh: The Jewish Bible. (2009). Varda Books.

Ibn Khaldun. (2000). Tarikh Ibn Khaldun (K. Shihadah, Ed.). Dar ul Fikr.

Ibn Khaldun, \& W. udeen A. R. (2004). Muqadimmah Ibn Khaldun (D. Abdullah Muhammad, Ed.; Vol. 1). Dar e Yu'rab.

Khaldûn, I. I., \& Lawrence, B. B. (2015). The Muqaddimah: An Introduction to History - Abridged Edition (N. J. Dawood, Ed.; F. Rosenthal, Trans.; Abridged edition). Princeton University Press.

Montefiore, S. S. (2011). Jerusalem: The Biography. Knopf Doubleday Publishing Group.

Pines, S. (1970). Ibn Khaldun and Maimonides, a compararison between two texts. https://doi.org/10.2307/1595224

Pro. Hillel Frisch. (2018, August 21). Ibn Khaldun and the Nation State Law. The Begin-Sadat Center For Strategic Studies.

Reuven Firestone. (n.d.). Children of Abraham: An Introduction to Judaism for Muslims. KTAV Publishing House.

Roy Jackson. (2006). Fifty Key Figures In Islam. Routledge.

Salime Leyla GÜRKAN. (n.d.). Some Implications of Ibn Khaldun's Approach to the History of The People of Israel: The Relation Between Asabiya and Chosenness. 
The Muqaddimah. (2015). https://press.princeton.edu/books/paperback/9780691166285/themuqaddimah

Walter J. Fischel. (2009). Ibn Khaldun's Use of Historical Sources. Maisonneuve \& Larose.

Wan Mohd Farzul Azadi Wan Razali. (2017). An Analysis of Ibn Khaldun's Study of other Religions in the Muqadimmah. University Kebangsaan Malaysia.

What Would Ibn Khaldun Say? - Israel National News. (n.d.). Retrieved 3 December 2021, from https://www.israelnationalnews.com/Articles/Article.aspx/4024

Yücekaya, M. (n.d.). A Thesis Submitted To The Graduate School Of Social Sciences Of Middle East Technical University. 133. 